\title{
PENGARUH AKASIA SEBAGAI BAHAN PENGIKAT TERHADAP MUTU FISIK TABLET HISAP EKSTRAK TEH HIJAU (Camellia sinensis)
}

\author{
Lidya Ameliana dan Fitri Wazni \\ Bagian Farmasetika, Fakultas Farmasi \\ Universitas Jember, Jember, \\ Telp./Fax. (0331) 324736, HP 081231198524 \\ e-mail : lidyaameliana@yahoo.co.id
}

\begin{abstract}
Formulation of green tea extract lozenges (Camellia sinensis) have been studied, the lozenges were made by direct compressing method. The purpose of this research is to know the effect of acacia as binding agent to the physical characteristic of the tablets. Fillers were combined using wet granulation with acacia with concentration of $1 \%, 2 \%$, and $3 \%$ respectively. Furthermore, the filler granuls mixed with green tea extract. Physical characteristic of granul including flow rate, angle of repose, particle size distribution, bulk density, tapped density, compressibility index, and moisture content. Then the extract granuls were pressed into tablet on a hydraulic press with diameter $16,71 \mathrm{~mm}$ and pressure of 4 ton, and physical characteristic of lozenges were examined. Evaluation on the green tea extract lozenges result including tablet size, tablet weight, hardness, friability, and dissolving time. The result of those evaluations showed that green tea extract lozenges fulfilled the requirement of tablet physical characteristics. The result showed that the increase of acacia concentration will increase hardness and prolonged dissolving time but the increase of acacia concentration will decrease the friability of lozenges.
\end{abstract}

Keywords : green tea extract, lozenges, acacia, physical characteristic, direct compression.

\begin{abstract}
ABSTRAK
Telah dilakukan formulasi tablet hisap ekstrak teh hijau (Camellia sinensis), dengan metode cetak langsung. Tujuan dari penelitian ini adalah untuk mengetahui pengaruh penambahan bahan pengikat akasia $1 \%, 2 \%$, dan $3 \%$ terhadap mutu fisik tablet hisap ekstrak teh hijau. Bahan pengisi dan bahan pengikat dikombinasikan dengan menggunakan granulasi basah dengan akasia sebagai bahan pengikat. Selanjutnya granul bahan pengisi tersebut dicampurkan dengan ekstrak teh hijau. Karakteristik fisik granul yang diuji meliputi laju alir, sudut istirahat, distribusi ukuran partikel, berat jenis nyata, berat jenis mampat, kompresibilitas, dan kandungan kelembaban. Setelah memeriksa karakteristik fisik campuran granul, kemudian dikompres menjadi tablet dengan diameter 16,71 mm dan tekanan 4 ton. Evaluasi pada ekstrak teh hijau meliputi ukuran tablet, massa tablet, kekerasan, kerapuhan, dan waktu larut. Hasil evaluasi menunjukkan bahwa tablet hisap ekstrak teh hijau memenuhi persyaratan karakteristik tablet fisik. Hasil penelitian ini menunjukkan bahwa peningkatan akasia akan meningkatkan kekerasan dan waktu melarut, namun akan mengurangi kerapuhan tablet hisap.
\end{abstract}

Kata kunci : ekstrak teh hijau, tablet hisap, akasia, karakteristik fisik, cetak langsung. 
Pengaruh Akasia Sebagai Bahan Pengikat Terhadap Mutu Fisik Tablet Hisap Ekstrak Teh Hijau (Camellia sinensis)

\section{PENDAHULUAN}

Teh merupakan bahan minuman yang secara universal dikonsumsi di banyak negara serta di berbagai lapisan masyarakat [18]. Bedasarkan cara pengolahannya, teh yang umum ada di Indonesia dibedakan menjadi tiga jenis yaitu teh hitam (black tealfermented tea), teh hijau (green teal unfermented tea), dan teh oolong (semifermented tea) [3].

Teh hijau dan teh hitam berasal dari tanaman yang sama yaitu Camellia sinensis, yang membedakan diantara keduanya adalah cara pembuatannya. Teh hijau dibuat dengan inaktivasi enzim polifenol melalui pemanasan dan penguapan. Teh hitam dibuat dengan fermentasi melalui oksidasi kation dalam daun segar [19]. Sedangkan teh oolong merupakan hasil dari pegolahan peralihan antara teh hijau dan teh hitam [3]. Pengolahan daun teh hijau tersebut mampu mempertahankan kandungan senyawa polifenol yang bersifat antioksidan [19].

Menurut hasil penelitian yang dilakukan di Jepang menyebutkan bahwa senyawa antioksidan polifenol yang terdapat dalam teh hijau mampu menekan resiko penyakit jantung, membunuh sel tumor, menghambat perkembangan sel kanker paru-paru, kanker usus, dan kanker kulit, mempunyai efek anti bakteri, anti virus anti kariogenik, efek menurunkan lemak, anti osteoporosis. Selain polifenol, teh hijau juga mengandung mineral florida. Mineral ini dapat mencegah perkembangan karies pada gigi, juga mencegah radang gusi, gigi berlubang dan mencegah halitosis (bau mulut) [9].

Selama ini teh disajikan dalam berbagai bentuk produk dan kemasan seperti teh kering kemasan, air teh dalam kemasan, dan teh instan [16]. Seiring dengan kemajuan zaman dan perkembangan teknologi, perlu dilakukan suatu diversifikasi produk yang bisa mempermudah konsumen untuk mengkonsumsi produk. Sediaan yang dibuat adalah tablet hisap ekstrak teh hijau.

Tablet hisap ini memiliki beberapa kelebihan yaitu melarut dalam mulut secara perlahan sehingga tidak memerlukan air, rasanya manis, dan pemakaiannya praktis. Tablet hisap adalah sediaan padat yang mengandung satu atau lebih bahan obat, umumnya dengan bahan dasar beraroma dan manis, yang dapat melarut atau hancur perlahan dalam mulut [2]. Penggunaan tablet hisap dimaksudkan untuk memberikan efek lokal pada rongga mulut atau kerongkongan tetapi dapat juga mengandung bahan obat yang dimaksudkan untuk diabsorbsi sistemik setelah dihisap [14].

Pemilihan metode pembuatan tablet harus dipertimbangkan dari studi praformulasi bahan obat antara lain dosis obat, sifat alir, kompresibilitas, stabilitas fisika kimia bahan obat dan bahan pembawa karena akan mempengaruhi tablet yang dihasilkan.

Pada pembuatan tablet hisap diperlukan komponen-komponen penyusun seperti halnya tablet biasa yaitu bahan pembawa, pengikat, lubrikan, flavor, pewarna kecuali disintegran. Persyaratan mutu fisik tablet hisap berbeda dengan tablet biasa, perbedaan tersebut diantaranya adalah kekerasan lebih tinggi (>10 kg). Jenis tablet ini dirancang agar tidak hancur di dalam rongga mulut tetapi melarut atau terkikis secara perlahan dalam waktu 30 menit atau kurang [16]. Sehingga bahan pengikat merupakan eksipien penting terutama dalam pembuatan tablet hisap secara kompresi. Penambahan bahan pengikat sebagai eksipien tablet dapat mempengaruhi mutu fisik tablet seperti 
kekerasan, kerapuhan dan juga memperlambat disolusi tablet dalam rongga mulut. Untuk memenuhi ketentuan tersebut, massa granul yang akan dicetak menjadi tablet harus memberikan gaya antar partikel yang kuat.

Bahan pengikat yang dapat digunakan untuk tablet hisap antara lain akasia, tragakan, sirup jagung, sirup gula, gelatin, metil selulosa, etil selulosa, polivinilpirolidon (PVP) dan HPMC. Bahan-bahan tersebut berfungsi untuk meningkatkan kekuatan antar granul dan juga memperbaiki tekstur permukaan tablet ketika melarut di dalam rongga mulut [14]. Akasia dapat membentuk formasi gel yang dapat menghambat pelepasan obat dari sediaan sehingga dapat terkikis perlahan dalam rongga mulut, hal ini sesuai dengan persyaratan dari tablet hisap yaitu menghasilkan pelepasan obat dalam mulut secara perlahan [20].

Berdasarkan uraian di atas, maka perlu dilakukan suatu penelitian untuk mengetahui pengaruh akasia sebagai bahan pengikat terhadap mutu fisik tablet hisap ekstrak teh hijau.

\section{METODE}

Pada penelitian ini dibuat 3 macam formula tablet hisap ekstrak teh hijau dengan perbedaan kadar bahan pengikat Akasia $0 \%, 1 \%, 2 \%$, dan $3 \%$.

Bahan yang digunakan dalam penelitian ini adalah Teh Hijau Merek Kepala Djenggot, Akasia (Valmar International Industries LTD.), Tragakan (PT. Brataco), Dekstrosa Monohidrat (Qinhuangdao Lihua Starch Co., LTD), PEG 4000 (PT. Brataco), CabO-Sil (PT. Brataco), Etanol 95\%, Aquadest, Reagen Follin Ciocalteu, $\mathrm{NaHCO}_{3}$, Asam Sitrat, dan $\mathrm{NaOH}$.
Alat-alat yang digunakan dalam penelitian ini adalah neraca analitik (Adventurer Ohaus), oven (Memmert), mikroskop, alat tumbling mixer, alat uji distribusi ukuran partikel (Sieve Shaker), alat uji sifat alir granul (Pharmex), alat uji kadar lembab (Ohaus MB 45), alat uji kompresibilitas (Erweka), alat pencetak tablet (Hidrolic Press), alat uji kekerasan tablet (Monsanto Hardness Tester), alat penguji kerapuhan (Pharmex), alat penguji waktu larut (Ika Labortecnik), Ultrasonic Cleaner (Elma E3OH), evaporator (Heidolph Laborota 4000), viskotester, spektrofotometer (Hitachi 1800), pH meter, mortir dan stamper, stopwatch, jangka sorong, blender, ayakan (20, 40 mesh), ayakan $\mathrm{B}_{50}$, dan alat-alat gelas.

\section{Pembuatan dan Evaluasi ekstrak Teh Hijau}

Pembuatan ekstrak teh hijau dilakukan sebagai berikut : simplisia kering daun teh hijau diblender, kemudian dilakukan pengayakan sampai didapat serbuk kering daun teh hijau dan ditimbang sebanyak 666,67 gram. Ekstraksi dilakukan dengan menambahkan 5 liter etanol $95 \%$ ke dalam serbuk teh hijau dan diremaserasi selama 3 hari. Maserat dikumpulkan, kemudian pelarut diuapkan menggunakan rotavapor selama 5 jam, sehingga didapatkan ekstrak cair. Ekstrak cair kemudian dikeringkan menggunakan oven bersuhu $50^{\circ} \mathrm{C}$ selama 14 hari, sehingga didapatkan ekstrak kental dan dilakukan pengujian ekstrak yang meliputi organoleptis, susut pengeringan, dan uji total polifenol.

Ekstrak kental yang didapat ditambahkan Cab-O-Sil sebayak 3\% dari berat ekstrak kental dan dihaluskan sampai menjadi ekstrak kering, kemudian diayak dengan ayakan $\mathrm{B}_{50}$ sehingga didapat serbuk kering ekstrak teh hijau. 
Selanjutnya dilakukan pengujian ekstrak yang meliputi :

(a). Organoleptis (warna, bau, dan rasa), (b). Susut pengeringan, dilakukan sebagai berikut : ekstrak ditimbang seksama sebanyak 2 gram dan dimasukkan ke dalam botol timbang dangkal bertutup yang sebelumnya telah dipanaskan pada suhu $105^{\circ} \mathrm{C}$ selama 30 menit dan telah ditara. Sebelum ditimbang, ekstrak diratakan dalam botol timbang, dengan bantuan pengaduk. Kemudian dimasukkan ke dalam oven, buka tutupnya, keringkan, pada suhu $105^{\circ} \mathrm{C}$ hingga bobot tetap. Sebelum setiap pengeringan, biarkan botol dalam keadaan tertutup mendingin dalam eksikator hingga suhu kamar. Kemudian keringkan kembali pada suhu penetapan hingga bobot tetap [4] dan dihitung persen susut pengeringan dengan rumus sebagai berikut :

$\%$ Susut Pengeringan $=\frac{\mathrm{m} \times \mathrm{a}}{\text { Berat ekstrak }} \times 100 \%$

Keterangan :

$\mathrm{m}=$ berat botol+ekstrak mula-mula $\mathrm{a}=$ berat botol+ekstrak akhir

(c). Analisis kadar total polifenol, Kadar polifenol diukur dengan metode pewarnaan dengan reagen Folin Ciocalteu [11].

Ditimbang ekstrak kental sebanyak $25 \mathrm{mg}$ dan dilakukan pengenceran sampai 300 ppm. Kemudian diambil sebanyak $100 \mu \mathrm{l}$ sampel ditambah dengan $100 \mu$ l larutan Folin Ciocalteu (50\%), ditambahkan $2 \mathrm{ml}$ natrium karbonat (2\%), campuran ini didiamkan selama 30 menit pada suhu kamar. Diukur absorbansinya pada panjang gelombang $750 \mathrm{~nm}$. Nilai absorbansi yang diperoleh dimasukkan ke dalam persamaan regresi larutan standar asam galat sehingga diperoleh kadar total fenolik yang ditunjukkan dengan miligram asam galat ekuivalen per gram berat kering (mgGAE/g).

\section{Pembuatan dan Evaluasi Granul Bahan Pembawa}

Dalam penelitian ini akan dibuat tablet hisap ekstrak teh hijau sebanyak 100 tablet per formula, dengan berat per tablet adalah $2000 \mathrm{mg}$. Pada pembuatan tablet hisap ekstrak teh hijau dimulai dengan pembuatan granul bahan pembawa yang terdiri dari bahan pengisi, dan pengikat secara granulasi basah. Komposisi granul bahan pembawa dapat dilihat pada tabel 1 .

Pembuatan granul bahan pembawa dilakukan dengan langkah-langkah sebagai berikut :

a. Pembuatan larutan pengikat

Ditimbang akasia sebanyak $(\mathrm{F} 1=2$ gram; $\mathrm{F} 2=4$ gram; $\mathrm{F} 3=6$ gram) kemudian dimasukkan dalam beker glas $50 \mathrm{ml}$, ditambahkan air panas bersuhu $80^{\circ} \mathrm{C}$ sebanyak ( $\mathrm{F} 1=13,33 \mathrm{ml} ; \mathrm{F} 2=26,66 \mathrm{ml}$; $\mathrm{F} 3=40 \mathrm{ml}$ ) dari $15 \% \mathrm{w} / \mathrm{v}$ larutan pengikat diaduk sampai terbentuk musilago.

b.Pembuatan granul bahan pembawa

Dekstrosa ditimbang dengan berat tertentu (tabel 1), dimasukkan dalam mortir kemudian ditambahkan larutan bahan pengikat sedikit demi sedikit ke dalam mortir dan diaduk kuat sehingga terbentuk massa granul. Massa granul selanjutnya diayak dengan pengayak mesh 20. Granul basah yang terbentuk dikeringkan dalam lemari pengering bersuhu $50{ }^{\circ} \mathrm{C}$ selama 2 jam. Granul kering kemudian diayak dengan pengayak mesh 40. Granul kering yang dihasilkan ditimbang dan selanjutnya dilakukan evaluasi mutu fisik granul meliputi sifat alir dan sudut diam, distribusi ukuran partikel, kadar lembab, dan kompresibilitas. 
Pengaruh Akasia Sebagai Bahan Pengikat Terhadap Mutu Fisik Tablet Hisap Ekstrak Teh Hijau (Camellia sinensis)

\section{Pencampuran Granul Pembawa dengan Ekstrak Teh Hijau}

Granul bahan pembawa ditambah dengan serbuk ekstrak teh hijau dicampur dalam pencampur bergulir selama 10 menit.
Campuran granul pembawa dan ekstrak teh hijau ditambah dengan lubrikan yaitu PEG 4000 , dicampur dalam pencampur bergulir selama 5 menit. Komposisi granul dan ekstrak teh hijau dapat dilihat pada tabel 2.

Tabel 1. Komposisi Granul Bahan Pembawa

\begin{tabular}{cccccc}
\hline \multirow{2}{*}{ Bahan } & \multirow{2}{*}{ Fungsi } & \multicolumn{4}{c}{ Formulasi (mg)/tablet } \\
\cline { 3 - 6 } & & F0 & F1 & F2 & F3 \\
\hline Dekstrosa & Pengisi & 1702 & 1682 & 1662 & 1642 \\
Akasia & Pengikat & - & 20 & 40 & 60 \\
\hline Jumlah & & 1702 & 1702 & 1702 & 1702 \\
\hline
\end{tabular}

$\mathrm{F} 0=$ bahan pengikat $0 \% ; \mathrm{F} 1=$ akasia $1 \% ; \mathrm{F} 2=$ akasia $2 \% ; \mathrm{F} 3=$ akasia $3 \%$

Tabel 2. Komposisi Granul dan Ekstrak Teh Hijau

\begin{tabular}{cc}
\hline Bahan & Jumlah $(\mathrm{mg})$ \\
\hline Granul pembawa & 1702 \\
Ekstrak teh hijau+ Cab-O-sil 3\% & 258 \\
PEG 4000(2\%) & 40 \\
Berat total & 2000 \\
\hline
\end{tabular}

\section{Evaluasi Campuran Granul Bahan Pembawa dengan Ekstrak Teh Hijau}

a. Penentuan Kecepatan Alir dan Sudut Diam

Untuk menentukan kecepatan alir dan sudut diam granul digunakan metode corong dengan cara sebagai berikut : (Cartensen, 1977)

Ditimbang 100 gram campuran granul bahan pembawa dengan ekstrak teh hijau dimasukkkan ke dalam corong dengan dasar lubang tertutup. Waktu pengukuran dilakukan pada saat dibukanya lubang corong sampai serbuk habis mengalir. Satuan kecepatan alir dinyatakan dalam gram/detik. Penentuan sudut diam dilakukan dengan cara mengukur tinggi dan jari-jari lingkaran kerucut granul yang terjadi setelah pengaliran, kemudian dihitung sudut yang terbentuk dari nilai tangen yang diperoleh.

\footnotetext{
J. Trop. Pharm. Chem. 2011. Vol 1. No. 3.

Sudut diam $=\alpha=\tan ^{-1}\left[\frac{\text { tinggi kerucut }(\mathrm{h})}{\text { jari }- \text { jari }(\mathrm{r})}\right]$

Kecepatan Alir $=\frac{\text { Berat granul }}{\text { Waktu alir }}$

\section{b. Kadar Lembab}

Penentuan kandungan lembab dapat diukur menggunakan alat Ohaus MB 45 dengan cara sebagai berikut : granul bahan pembawa dengan ekstrak teh hijau \pm 1 gram dicampur pada pan, lalu diratakan. Proses pengeringan berlangsung selama 10 menit pada suhu $100^{\circ} \mathrm{C}$. Baca \% kadar lembab granul pada alat. Kadar lembab granul ditentukan $0,75 \%-2,0 \%$ [14].

\section{c. Pemeriksaan Bobot Jenis Nyata}

Pemeriksaan bobot jenis nyata [6] dilakukan sebagai berikut:

Ditimbang gelas ukur $100 \mathrm{ml}\left(\mathrm{W}_{1}\right)$, kemudian campuran granul bahan 
pembawa dengan ekstrak teh hijau dimasukkan ke dalam gelas ukur sampai volume $100 \mathrm{ml}$. Gelas ukur yang telah berisi campuran granul bahan pembawa dengan ekstrak teh hijau tersebut kemudian ditimbang $\left(\mathrm{W}_{2}\right)$ dan dihitung robot jenis nyata dengan rumus sebagai berikut :

$$
\mathrm{BJn}=\frac{\mathrm{W}_{2}-\mathrm{W}_{1}}{100}\left(\frac{\mathrm{gram}}{\mathrm{ml}}\right)
$$

\section{d. Pemeriksaan Bobot Jenis Mampat}

Pemeriksaan bobot jenis mampat dilakukan dengan cara [6] sebagai berikut :

Dimasukkan campuran granul bahan pembawa dengan ekstrak teh hijau ke dalam gelas ukur $100 \mathrm{ml}$ sampai tanda (100 $\mathrm{ml}$ ). Kemudian gelas ukur yang telah berisi campuran granul bahan pembawa dengan ekstrak teh hijau tersebut dilakukan pengetukan sampai didapatkan volume yang tetap.

Bobot jenis mampat dihitung sebagai berikut :

$$
\mathrm{BJm}=\frac{\mathrm{W}_{2}-\mathrm{W}_{1}}{\mathrm{~V}}\left(\frac{\mathrm{gram}}{\mathrm{ml}}\right)
$$

\section{e. Persen Kompresibilitas}

Persen kompresibilitas dihitung sebagai berikut :

$$
\begin{aligned}
& \text { Persen kompresibilitas }=\frac{\mathrm{BJm}-\mathrm{BJn}}{\mathrm{BJm}} \times 100 \% \\
& \begin{aligned}
\text { Keterangan } & : \\
\text { BJm } & =\text { bobot jenis mampat } \\
\text { BJn } & =\text { bobot jenis nyata }
\end{aligned}
\end{aligned}
$$

\section{Pencetakan Tablet Hisap Ekstrak Teh Hijau}

Hasil campuran ditimbang sebanyak 2000 $\mathrm{mg}$ masing-masing formula dan selanjutnya dicetak dengan pencetak hidrolik dengan diameter $16,71 \mathrm{~mm}$ dan kekuatan kompresi 4 ton dan dilakukan evaluasi mutu fisik tablet.

\section{Evaluasi Mutu Fisik Tablet Hisap Ekstrak Teh Hijau}

Evaluasi tablet yang dilakukan meliputi keseragaman bobot tablet, keseragaman ukuran tablet, kekerasan, kerapuhan, dan waktu larut.

\section{a. Keseragaman Bobot Tablet}

Evaluasi bobot tablet dilakukan dengan prosedur sebagai berikut : ditimbang 20 tablet satu per satu, kemudian dihitung bobot rata-rata tiap tablet. Persyaratan yang ditentukan, tidak boleh lebih dari dua tablet yang masing-masing bobotnya menyimpang dari harga yang ditetapkan kolom A, dan tidak satu tabletpun yang bobotnya menyimpang dari bobot rataratanya lebih dari yang ditetapkan pada kolom [1]. Persyaratan penyimpangan bobot tablet dapat dilihat pada tabel 3 .

\section{b. Keseragaman ukuran tablet}

Dengan menggunakan jangka sorong, tebal tablet di ukur sebagai berikut: Tablet ditekan di tengah-tengah penjepit dalam posisi berdiri, kemudian ditekan hingga tablet tidak bergerak lagi. Skala pada jangka sorong dibaca dalam satuan milimeter. Persyaratan yang ditentukan yaitu diameter tablet tidak lebih dari tiga kali dan tidak kurang satu sepertiga tebal tablet [1].

\section{c. Uji kekerasan}

Uji kekerasan dilakukan untuk mengetahui seberapa besar beban maksimal yang bisa diberikan pada tablet sehingga tablet dapat pecah. 
Pengaruh Akasia Sebagai Bahan Pengikat Terhadap Mutu Fisik Tablet Hisap Ekstrak Teh Hijau (Camellia sinensis)

Evaluasi kekerasan tablet dilakukan dengan alat penguji kekerasan (Hardness tester) dengan cara sebagai berikut : skala pada alat mula-mula dibuat nol, tablet diletakkan pada tempat yang tersedia pada alat tersebut dengan posisi tegak. Kemudian tempat tersebut diputar sampai menunjukkan bahwa tablet sudah tidak bergerak lagi dan siap untuk diuji kekerasannya.

Sekrup kemudian diputar sampai tabletnya pecah. Pada saat tablet pecah, skala dibaca yang dinyatakan dalam satuan kilogram. Untuk tablet yang diuji kekerasannya berjumlah 10 tablet [10].

Tabel 3. Persyaratan Penyimpangan Bobot Tablet

\begin{tabular}{lcc}
\hline \multirow{2}{*}{ Bobot rata-rata } & \multicolumn{2}{c}{ Penyimpangan bobot rata-rata dalam \% } \\
\cline { 2 - 3 } & $15 \%$ & B \\
\hline $25 \mathrm{mg}$ atau kurang & $10 \%$ & $30 \%$ \\
$25 \mathrm{mg}-150 \mathrm{mg}$ & $7.5 \%$ & $20 \%$ \\
$151 \mathrm{mg}-300 \mathrm{mg}$ & $5 \%$ & $15 \%$ \\
Lebih dari $300 \mathrm{mg}$ & & $10 \%$ \\
\hline
\end{tabular}

\section{d. Uji kerapuhan}

Uji kerapuhan digunakan untuk mengetahui ketahanan dan kekuatan tablet terhadap guncangan yang ditimbulkan. Evaluasi kerapuhan tablet dilakukan dengan alat Pharmeq sebagai berikut : sebanyak 20 buah tablet dibersihkan secara hati-hati dan ditimbang $\left(\mathrm{W}_{1}\right)$. Tablet kemudian dimasukkan secara perlahanlahan ke dalam drum alat Pharmeq. Alat dijalankan dengan kecepatan $25 \mathrm{rpm}$ selama 4 menit. Selanjutnya tablet dikeluarkan dari alat dan dibersihkan dari serbuk yang menempel, lalu ditimbang lagi $\left(\mathrm{W}_{2}\right)$. Kekurangan berat menunjukkan kerapuhan dari tablet yang dinyatakan dengan persen [10].

\section{e. Uji waktu larut}

Pemeriksaan waktu melarut tablet hisap dilakukan dengan cara sebagai berikut : Beker glass diisi dengan $800 \mathrm{ml}$ larutan buffer asam sitrat dan natrium hidroksida $\mathrm{pH}$ 6,75 dengan suhu $37{ }^{\circ} \mathrm{C}$, setelah itu tablet dimasukkan ke dalam beker glass dan diputar dengan menggunakan stirer dengan kecepatan $150 \mathrm{rpm}$, dan dihitung waktu sampai tablet melarut habis [13].

Tablet hisap dimaksudkan untuk melarut secara perlahan di mulut atau terkikis secara perlahan-lahan dalam waktu 30 menit atau kurang [6].

\section{HASIL DAN PEMBAHASAN}

Pada proses ekstraksi teh hijau dari 666,67 gram simplisia kering daun teh hijau (Camellia sinensis) diremaserasi dan dihasilkan filtrat ekstrak teh hijau sebanyak 4,5 liter, Filtrat kemudian dirotavapour selama 5 jam dan didapatkan ekstrak cair sebesar 169,21 gram, selanjutya dilakukan pengeringan dengan oven $50{ }^{\circ} \mathrm{C}$ selama 14 hari, didapatkan ekstrak kental sebesar 153,88 gram sehingga diperoleh \% rendemen ekstrak teh hijau sebesar $23,08 \%$, ekstrak kental yang diperoleh ditambahkan dengan cab-o-sil sebesar 4,62 gram (3\% dari berat ekstrak kental) sehingga didapatkan ekstrak kering sebesar 158,5 gram. 
Pengaruh Akasia Sebagai Bahan Pengikat Terhadap Mutu Fisik Tablet Hisap Ekstrak Teh Hijau (Camellia sinensis)

\section{Hasil Pengujian Ekstrak Teh Hijau}

\section{a. Organoleptis}

Pemeriksaan Ekstrak teh hijau dilakukan secara kualitatif meliputi bau, warna, dan rasa. Hasil pemeriksaan kualitatif ekstrak teh hijau dapat dilihat pada tabel 4 .

Hasil Ekstrak kental dan kering dapat dilihat pada gambar 1 dan gambar 2 .

\section{b. Susut pengeringan}

Hasil pengujian susut pengeringan dapat dilihat pada tabel 5. Pada uji susut pengeringan ekstrak kental teh hijau didapatkan hasil persen susut pengeringan sebesar 4,20 $\pm 0,24 \%$. Susut pengeringan dalam literatur dibatasi sekitar 3-5\% (Voigt, 1995). Sehingga hasil susut pengeringan ekstrak teh hijau sudah memenuhi persyaratan sesuai dengan literatur.

\section{c. Kadar total polifenol}

Hasil pembuatan kurva baku standar asam galat adalah seperti pada gambar 3 .

Hasil uji total polifenol ekstrak kental teh hijau tampak pada tabel 6 .

\section{Evaluasi Campuran Granul Bahan Pembawa dengan Ekstrak Teh Hijau}

Pembuatan granul bahan pembawa dilakukan dengan metode granulasi basah. Hal ini ditujukan untuk memperoleh ikatan antar granul yang kuat, dimana partikel serbuk akan disalut oleh larutan bahan pengikat sehingga pertikelnya melekat satu sama lain membentuk granul yang mempunyai kohesifitas dan kompresibilitas yang cukup tinggi, sehingga setelah tahap pencetakan akan dihasilkan tablet hisap dengan kekerasan yang tinggi dan melarut secara perlahan tanpa mengalami disintegrasi [15].

Penentuan Kecepatan Alir dan Sudut Diam Hasil evaluasi sudut diam dan kecepatan alir campuran granul bahan pembawa dengan ekstrak teh hijau dapat dilihat pada Tabel 7.

\section{b. Kadar Lembab}

Hasil evaluasi kadar lembab dapat dilihat pada tabel 8 .

\section{c. Pemeriksaan \% kompresibilitas}

Hasil pemeriksaan \% kompresibilitas dari keempat formula campuran antara granul bahan pembawa dengan ekstrak teh hijau dapat dilihat pada tabel 9 .

Sifat alir granul juga berkaitan dengan prosen kompresibilitas. Prosen kompresibilitas menggambarkan penurunan volume massa serbuk sebelum terkena gaya dari punch pada mesin pencetak tablet. Selain itu prosen kompresibilitas dapat juga digunakan untuk mengetahui kemampuan alir massa granul yang akan dicetak. Sebelum menentukan prosen kompresibilitas kita harus mengetahui terlebih dahulu berapa besar nilai bobot jenis nyata (BJn) dan bobot jenis mampat (BJm) suatu granul.

Berdasarkan hasil di atas, dapat diambil kesimpulan bahwa semakin besar konsentrasi pengikat yang digunakan dalam formula, maka semakin baik kemampuan alir granul. Hal ini disebabkan dengan peningkatan konsentrasi pengikat, maka semakin kuat jembatan padat, yang berakibat porositas granul berkurang sehingga bobot jenis dan persen kompresibilitas granul meningkat. 
Tabel 4. Hasil Pemeriksaan Kualitatif Ekstrak teh hijau

\begin{tabular}{cccc}
\hline No & Pemeriksaan & Ekstrak Kental & Ekstrak Kering \\
\hline 1 & Bau & Aromatik & Aromatik \\
2 & Warna & Hijau gelap kecoklatan & Hijau seperti daun segar \\
3 & Rasa & Pahit & Pahit \\
\hline
\end{tabular}

Tabel 5. Hasil Pengujian Susut Pengeringan Ekstrak Teh Hijau

\begin{tabular}{cc}
\hline Replikasi & Susut Pengeringan $(\%)$ \\
\hline 1 & 4,25 \\
3 & 3,94 \\
Rata-rata \pm SD & 4,42 \\
\end{tabular}

Gambar 1 Ekstrak Kental Teh Hijau

Gambar 2 Ekstrak Kering Teh Hijau

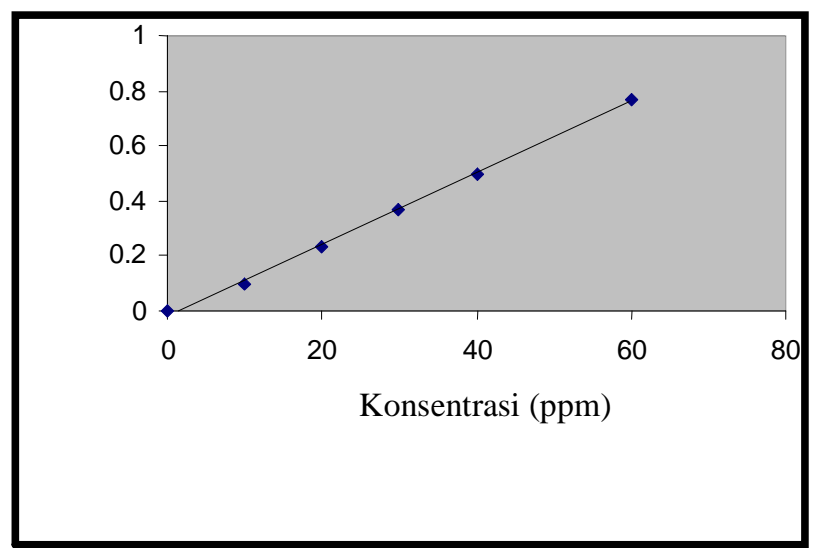

Gambar 3. Kurva Baku Standar Asam Galat pada $750 \mathrm{~nm}(y=0,013 x-0,0206$; $\left.R^{2}=0,998\right)$

Tabel 6. Hasil Kadar Total Polifenol

\begin{tabular}{cc}
\hline Replikasi & Kadar total polifenol (mg GAE/0,025 g) \\
\hline 1 & 35,07 \\
2 & 34,54 \\
3 & 34,89 \\
Rata-rata \pm SD & $34,83 \pm 0,26$ \\
\hline
\end{tabular}

Tabel 7. Hasil Evaluasi Sudut Diam Granul dan Kecepatan Alir

\begin{tabular}{|c|c|c|c|c|}
\hline Pemeriksaan & F0 & F1 & $\mathrm{F} 2$ & $\mathrm{~F} 3$ \\
\hline Rata-rata kecepatan alir $(\mathrm{g} /$ det $) \pm \mathrm{SD}$ & $7,33 \pm 0,10$ & $8,02 \pm 0,05$ & $8,17 \pm 0,10$ & $8,36 \pm 0,11$ \\
\hline Rata-rata sudut diam $\left({ }^{\circ}\right) \pm \mathrm{SD}$ & $32,00 \pm 0,40$ & $30,95 \pm 0,61$ & $30,34 \pm 0,62$ & $29,92 \pm 0,35$ \\
\hline
\end{tabular}

Setiap pengujian dilakukan pengulangan 3 kali.

J. Trop. Pharm. Chem. 2011. Vol 1. No. 3. 
Tabel 8. Hasil Uji Kadar Lembab (pengujian dilakukan dengan $3 x$ replikasi)

\begin{tabular}{ccccc}
\hline Replikasi & F 0 (\%) & F 1 (\%) & F2 (\%) & F3 (\%) \\
\hline 1 & 1,72 & 1,74 & 1,84 & 1,87 \\
2 & 1,72 & 1,74 & 1,84 & 1,88 \\
3 & 1,73 & 1,73 & 1,85 & 1,88 \\
Rata-rata \pm SD & $1,72 \pm 0,006$ & $1,74 \pm 0,006$ & $1,84 \pm 0,006$ & $1,88 \pm 0,006$ \\
\hline
\end{tabular}

Setiap pengujian dilakukan pengulangan 3 kali.

Tabel 9. Hasil Uji BJn, BJm dan Prosen Kompresibilitas

\begin{tabular}{lcccc}
\hline \multicolumn{1}{c}{ Pemeriksaan } & F 0 (\%) & F 1 (\%) & F2 (\%) & F3 (\%) \\
\hline Rata-rata BJn(\%) \pm SD & $0,64 \pm 0,01$ & $0,54 \pm 0,02$ & $0,54 \pm 0,01$ & $0,51 \pm 0,01$ \\
Rata-rata BJm(\%) \pm SD & $0,70 \pm 0,01$ & $0,61 \pm 0,02$ & $0,58 \pm 0,01$ & $0,55 \pm 0,01$ \\
Rata-rata persen -kompresibilitas $(\%) \pm$ SD & $7,97 \pm 0,04$ & $9,99 \pm 0,03$ & $7,98 \pm 0,08$ & $7,01 \pm 0,06$ \\
\hline
\end{tabular}

Setiap pengujian dilakukan pengulangan 3 kali.

Tabel 10. Evaluasi Mutu Fisik Tablet Hisap Ekstrak Teh Hijau dengan Bahan Pengikat Akasia

\begin{tabular}{|l|c|c|c|c|}
\hline \multicolumn{1}{|c|}{ Evaluasi } & F & F1 & F2 & F3 \\
\hline Keseragaman bobot (g) & $1,984 \pm 0,008$ & $1,988 \pm 0,006$ & $1,986 \pm 0,005$ & $1,983 \pm 0,007$ \\
Ukuran & & & & \\
- Diameter (mm) & $16,71 \pm 0,07$ & $16,69 \pm 0,07$ & $16,72 \pm 0,08$ & $16,69 \pm 0,06$ \\
$-\quad$ Tebal (mm) & $5,62 \pm 0,02$ & $5,61 \pm 0,01$ & $5,63 \pm 0,02$ & $5,63 \pm 0,02$ \\
Kekerasan (kg) & $4,50 \pm 0,41$ & $10,25 \pm 0,26$ & $12,20 \pm 0,26$ & $13,95 \pm 0,37$ \\
Kerapuhan (\%) & $2,70 \pm 0,03$ & $0,95 \pm 0,01$ & $0,91 \pm 0,01$ & $0,88 \pm 0,01$ \\
Waktu Larut (menit) & $11,86 \pm 0,61$ & $14,92 \pm 0,35$ & $16,72 \pm 0,41$ & $18,03 \pm 0,44$ \\
\hline
\end{tabular}

\section{Evaluasi Mutu Fisik Tablet Hisap Ekstrak Teh Hijau}

Evaluasi mutu fisik tablet meliputi keseragaman bobot, keseragaman ukuran tablet, kekerasan, kerapuhan, waktu larut. Hasil evaluasi mutu fisik tablet dapat dilihat pada tabel 10 .

Hasil evaluasi keseragaman bobot keempat formula memenuhi persyaratan Farmakope Indonesia IV yaitu tidak ada lebih dari dua tablet yang masing-masing bobotnya menyimpang dari harga yang ditetapkan kolom A, dan tidak ada satu tabletpun yang bobotnya menyimpang dari bobot rataratanya lebih dari yang ditetapkan pada kolom B dan hasil evaluasi keseragaman ukuran tablet ketujuh formula memenuhi persyaratan yang ditentukan dalam Farmakope Indonesia IV yaitu diameter tablet tidak lebih dari tiga kali dan tidak kurang satu sepertiga tebal tablet.
Kekerasan tablet merupakan parameter yang menggambarkan ketahanan tablet dalam melawan tekanan mekanik seperti goncangan, benturan, dan terjadi keretakan tablet selama pengemasan, penyimpanan, transportasi, sampai ke tangan konsumen. Faktor-faktor yang mempengaruhi kekerasan tablet adalah tekanan kompresi dan sifat bahan yang akan dikempa [17].

Dari hasil evaluasi kekerasan terlihat bahwa F1 - F3 memiliki kekerasan antara $10,25 \pm 0,26 \mathrm{kP}-13,95 \pm 0,37 \mathrm{kP}$ yang berarti memenuhi persyaratan yaitu antara 10 - 25 kP [12]. Sedangkan F0 memiliki kekerasan 4,50 $\pm 0,41 \mathrm{kP}$. Sehingga tidak memenuhi persyaratan untuk kekerasan tablet yang baik, hal ini disebabkan karena F0 merupakan formula tanpa bahan pengikat sehingga tidak memiliki daya ikat antar partikel. Persyaratan kekerasan tablet yang baik adalah 10 sampai $25 \mathrm{~kg}$ [12], sedangkan $1 \mathrm{~kg}=1 \mathrm{kP}$ [8], maka kekerasan tablet yang baik adalah 10-25 kP. Grafik 
kekerasan tablet dalam berbagai formula tampak pada gambar 4 .

Kekerasan tablet merupakan parameter yang menggambarkan ketahanan tablet dalam melawan tekanan mekanik seperti goncangan, benturan, dan terjadi keretakan tablet selama pengemasan, penyimpanan, transportasi, sampai ke tangan konsumen. Faktor-faktor yang mempengaruhi kekerasan tablet adalah tekanan kompresi dan sifat bahan yang akan dikempa [17]

Dari hasil evaluasi kekerasan terlihat bahwa F1 - F3 memiliki kekerasan antara $10,25 \pm 0,26 \mathrm{kP}-13,95 \pm 0,37 \mathrm{kP}$ yang berarti memenuhi persyaratan yaitu antara 10 - 25 kP [12]. Sedangkan F0 memiliki kekerasan 4,50 $\pm 0,41 \mathrm{kP}$. Sehingga tidak memenuhi persyaratan untuk kekerasan tablet yang baik, hal ini disebabkan karena F0 merupakan formula tanpa bahan pengikat sehingga tidak memiliki daya ikat antar partikel. Persyaratan kekerasan tablet yang baik adalah 10 sampai $25 \mathrm{~kg}$ [12], sedangkan $1 \mathrm{~kg}=1 \mathrm{kP}$ [8], maka kekerasan tablet yang baik adalah 10-25 kP. Grafik kekerasan tablet dalam berbagai formula tampak pada gambar 4 .

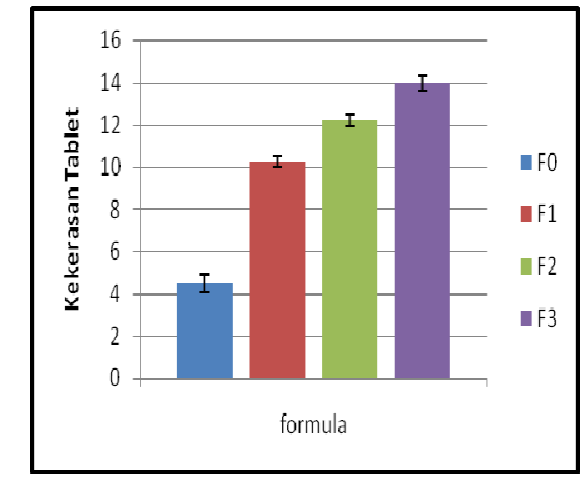

Gambar 4. Gambar Kekerasan Tablet Hisap Ekstrak Teh Hijau pada Berbagai Formula

Dari gambar 4 dapat diketahui bahwa peningkatan konsentrasi pengikat akasia akan meningkatkan kekerasan tablet hisap ekstrak teh hijau.

Hal ini disebabkan karena dengan meningkatnya konsentrasi bahan pengikat maka akan meningkatkan daya ikat granul sehingga tablet yang dihasilkan juga lebih keras. Kekerasan tablet hisap dipersyaratkan lebih tinggi dari tablet yang lain dengan harapan bahwa waktu melarutnya akan lebih lama, sehingga tablet hisap diharapkan akan menghasilkan efek terapi yang memadai [6].

Hasil analisis statistik kekerasan didapatkan bahwa nilai $\mathrm{p}=0,000$ dan kurang dari 0,05, sehingga dapat dikatakan bahwa kekerasan antar formula menunjukkan ada perbedaan bermakna minimal satu pasang. Dari uji HSD (Honestly Significant Difference) diketahui bahwa terdapat perbedaan bermakna kekerasan antara semua formula (F1, F2, dan F3).

Kerapuhan mengambarkan kekuatan tablet yang berhubungan dengan kekuatan ikatan partikel pada bagian tepi atau permukaan tablet. Uji kerapuhan berhubungan dengan kehilangan bobot akibat abrasi yang terjadi pada permukaan tablet. Semakin besar harga prosentase kerapuhan, maka semakin besar massa tablet yang hilang [17]. Pada evaluasi kerapuhan tablet menunjukkan bahwa F0 memberikan kerapuhan yang tidak memenuhi persyaratan yaitu $2,70 \pm 0,03 \%$, hal ini dikarenakan pada F0 tanpa menggunakan bahan pengikat, tidak memiliki daya ikat antar partikel, sehingga tidak menghasilkan tablet yang kompak. Sedangkan Hasil uji kerapuhan tablet pada F1 - F3 antara $0,88 \pm 0,005 \%-0,95 \pm 0,01 \%$ memenuhi persyaratan yaitu $<1 \%$ [10].

Hasil plotting konsentrasi pengikat terhadap kerapuhan tampak pada Gambar 5. 
Dari gambar 5 dapat diketahui bahwa peningkatan konsentrasi pengikat akasia akan menurunkan kerapuhan tablet hisap ekstrak teh hijau.

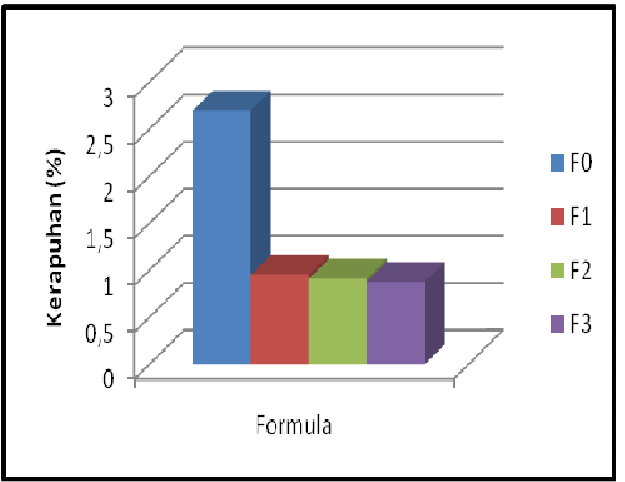

Gambar 5. KerapuhanTablet Hisap Ekstrak Teh Hijau pada Berbagai Formula

Penurunan kerapuhan tablet dengan adanya peningkatan konsentrasi pengikat terjadi karena terbentuknya jembatan padat karena adanya difusi molekular dari satu partikel ke partikel yang lain, jembatan padat bisa terbentuk karena oleh reaksi kimia, kristalisasi dari zat larut, pengerasan dari pengikat, dan pemadatan dari komponen yang melebur [5]. Proses ini menyebabkan ikatan antar partikel granul menjadi semakin kuat sehingga kerapuhan semakin menurun.

Dari hasil analisis statistik didapatkan bahwa nilai $\mathrm{p}=0,000$ dan kurang dari 0,05 sehingga dapat dikatakan bahwa kerapuhan antar formula menunjukkan ada perbedaan bermakna minimal sepasang. Formula yang berbeda dapat diketahui dengan uji HSD (Honestly Significant Difference). Dari uji HSD diketahui bahwa diketahui bahwa terdapat perbedaan bermakna kerapuhan antara semua formula (F1, F2, dan F3).

Hasil evaluasi waktu larut tablet dari keempat formula tablet memenuhi persyaratan waktu larut yaitu tidak lebih dari 30 menit [5]. Pada F1 - F3 memiliki waktu larut antara $14,92 \pm 0,35$ menit -
18,03 $\pm 0,44$ menit. Pada F0 didapatkan hasil waktu melarut yang lebih singkat dibandingkan dengan formula lainnya yaitu $11,86 \pm 0,61$ menit. Hal ini berkaitan dengan konsentrasi bahan pengikat dimana pada F0 tidak menggunakan bahan pengikat sehingga tidak ada daya ikatan antar partikel yang menghalangi pelepasan partikel penyusun tablet sehingga waktu larutnya menjadi lebih singkat dibandingkan dengan formula lainnya.

Hasil plotting konsentrasi pengikat terhadap waktu larut tampak pada Gambar 6. Dari gambar 6 dapat diketahui bahwa peningkatan konsentrasi pengikat akasia akan memperlama waktu larut tablet hisap ekstrak teh hijau. Semakin tinggi konsentrasi bahan pengikat dalam formula, semakin kuat daya ikat (adhesi) antar bahan sehingga mengakibatkan tablet sulit larut dan waktu larut tablet pun menjadi semakin lama.

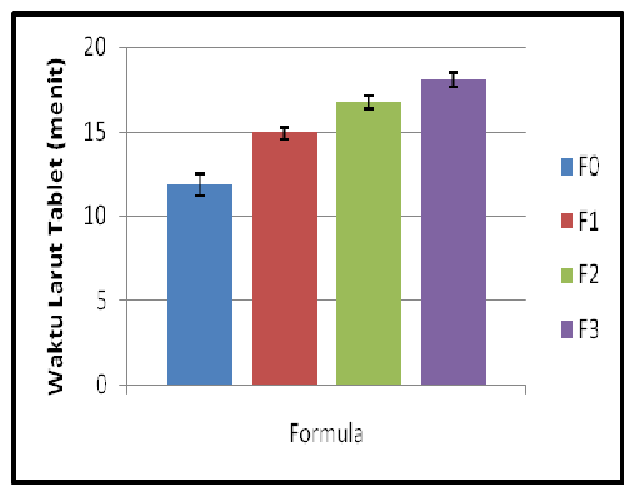

Gambar 6. Waktu Larut Tablet Hisap Ekstrak Teh Hijau pada Berbagai Formula

Pada evaluasi waktu melarut didapatkan bahwa harga F0 lebih rendah dibandingkan dengan formula yang lain, hal ini membuktikan bahwa penambahan pengikat, selain meningkatkan kekerasan juga menigkatkan waktu melarut, hal ini sangat menguntungkan tablet hisap kerena tujuan tablet hisap adalah agar bahan aktif 
Pengaruh Akasia Sebagai Bahan Pengikat Terhadap Mutu Fisik Tablet Hisap Ekstrak Teh Hijau (Camellia sinensis)

dapat dilepaskan secara perlahan dirongga mulut untuk mendapatkan efek lokal maupun sistemik yang lama. Dari analisis statistik didapatkan bahwa nilai $\mathrm{p}=0,000$ dan lebih kecil dari 0,05 sehingga dapat dikatakan bahwa waktu melarut antar formula menunjukkan ada perbedaan bermakna. Formula yang berbeda dapat diketahui dengan uji HSD. Dari uji HSD diketahui bahwa terdapat perbedaan bermakna waktu larut tablet antara semua formula.

\section{KESIMPULAN}

Dari hasil penelitian dapat disimpulkan bahwa:

1. Mutu fisik (organoleptis, kekerasan, kerapuhan, dan waktu melarut) sediaan tablet hisap ekstrak teh hijau dengan penambahan akasia sebagai bahan pengikat memenuhi persyaratan.

2. Semakin tinggi konsentrasi akasia menyebabkan kekerasan tablet hisap ekstrak teh hijau makin tinggi, kerapuhan makin rendah, dan waktu melarut makin lama.

\section{DAFTAR PUSTAKA}

1. Departemen Kesehatan RI. 1979, Farmakope Indonesia. Edisi III. Jakarta: Direktorat Jendral Pengawasan Obat dan Makanan Departemen Kesehatan Republik Indonesia.

2. Departemen Kesehatan RI. 1995, Farmakope Indonesia Edisi IV. Jakarta: Direktorat Jendral Pengawasan Obat dan Makanan Departemen Kesehatan Republik Indonesia.

3. Anonim. 1996, Teh : Pembudidayaan dan Pengolahan. Jakarta: Penebar Swadaya.

4. Departemen Kesehatan RI. 2000, Parameter Standar Umum Ekstrak Tumbuhan Obat. Jakarta: Departemen Kesehatan, p. 6, 10-11.

5. Augsburger, L.L.; \& Vuppala, M.K. 1997, Theory of Granulation in: Parikh, D.M, Eds. Handbook of Pharmaceutical Granulation Technology. New York: Marcel Dekker Inc, p.10
6. Banker G.S.; \& Anderson, N.R. 1986, Tablet dalam: Lachman, L., dan Lieberman, H. A., Teori dan Praktek Farmasi Industri, Edisi III. Universitas Indonesia Press, p. 293-343.

7. Cartensen, J.T.; \& Chan, P.C. 1977, Flow Rates and Respose Angel of Wet Processses Granulation. J. Pharm. Sci vol 66.

8. Cooper, D.; \& Carter, S. (Tanpa Tahun). Mechanical Strengh Testing Machine Some Information on Tablet Hardness Testing. England: Engineering Systems (Nottm) Ltd. http://www.engsys.co.uk/

9. Hara, Y. 2001, Green Tea Health Benefits and Applications. Japan: Tokyo Food Techno Co., Ltd. (Mitsui Nor in Co., Ltd.) http:/ /www.dekker.com. [14 April 2008]

10. Lachman, L.; Herbert, A.L.; \& Joseph, L.K. 1994, Teori dan Praktek Farmasi Industri II. Jakarta: Indonesia University Press.

11. Marinova, D.; Ribarova, F.; \& Atanassova, M. 2005, Total Phenolics and Total Flavonoids in Bulgarian Fruits and Vegetables. $J$. the University of Chem. Technology and Metallurgy, 40 (3): 225-260.

12. Parrot, E.L. 1970, Pharmaceutical Technology Fundamental Pharmaceuties. Minnepolis USA: urges Publishing Company, p. 73-85

13. Perioli, L.; Ambrogi, V.; Giovagnoli, S.; Ricci, M.; Blasi, P.; \& Rossi, C. 2007, Mucoadhesive Bilayered Tablets for Buccal Sustained Release of Flurbiprofen. AAPS PharmSciTech 2003. 8 (3): Article 54.

14. Peter, D. 1980, Medical Lozenges, in: Liberman, H.A., Lachman, L,. and Schartz., I. B., Eds., Pharmaceutical Dosage Form Tablet. Vol. I., $2^{\text {th }}$ ed. New York: Marcel Dekker.

15. Sheth. Bhogi, B.; et al. 1980, Compressed Tablet, In : Lieberman, H.A., Lachman, L., Pharmaceutical Dosage Form: Tablets, $2^{\text {nd }}$ Edition. New York: Marcell Dekker Inc..

16. Sugiarto.; \& M.Z. Nasutioan. 1998, Pembuatan Teh Effervescent Sebagai Alternatif Diversifikasi Produk Teh. Jurnal Teknologi Industri Pertanian Vol. 9 (2), p. 101-109.

17. Sulaiman.; \& T.N., Saifullah. 2007, Teknologi dan Formulasi Sediaan Obat. Yoyakarta: Laboratorium Teknologi Farmasi Fakultas Farmasi Universitas Gajah Mada.

18. Sulistyowati, T. 2004, Teh sebagai Salah Satu Sumber Antioksidan. Jakarta: Pusat Penelitian dan Pengembangan Pemberantasan Penyakit Badan Penelitian 
Pengaruh Akasia Sebagai Bahan Pengikat Terhadap Mutu Fisik Tablet Hisap Ekstrak Teh Hijau (Camellia sinensis)

dan Pengembangan Kesehatan Departemen Kesehatan RI. [12 Mei 2008]

19. Syah, A.N. 2006. Taklukkan Penyakit dengan Teh Hijau. Bintaro: PT. Agromedia Pustaka, p. 1-33, 41, 59-60.
20. Voigt, R. 1994. Buku Pelajaran Teknologi Farmasi. Yogyakarta: Gadjah Mada University Press. 